\title{
CARTOGRAFIA E TELEDETECÇÃO NA OBRA CIENTÍFICA DE SUZANNE DAVEAU
}

\author{
M. EUGÉNIA S. DE A. MOREIRA ${ }^{1}$
}

\section{O ENCANTO PELA CARTOGRAFIA}

Em toda a obra de Suzanne Daveau se nota a forma cuidada e a expressividade científica das representações gráficas. Defensora do provérbio islâmico «uma imagem vale mais que mil palavras», aplicou-o nos seus trabalhos, com expressões diversas, e o ensinou aos alunos e discípulos, com tal veemência que nenhum deles apresenta um mapa sem escala, sem título ou sem legenda! A preocupação pedagógica por este tema está marcada na sua actividade docente e em algumas publicações elaboradoas com esse fim.

A dedicação à cartografia propriamente dita é manifesta desde as suas primeiras obras, na abundância e no cuidado do uso de mapas e esboços, desde os mais simples, de localização, aos mapas temáticos, como os numerosos mapas geomorfológicos que ilustram, sem excepção, todas as publicações de geomorfologia, a alguns publicados como obra principal, acompanhados de uma notícia explicativa que é quase um livro. É o caso dos mapas da precipitação de Portugal (1977), e dos nevoeiros, da nebulosidade e dos contrastes térmicos $(1985)^{2}$. Estes últimos constituem experiência ou contribuições para um Atlas de Portugal, cuja preparação a autora anuncia em 1988, sem, no entanto, lhe dar seguimento, dada a vastidão e a complexidade da obra.

Estes trabalhos de cartografia temática constituem obras de grande valor científico, usadas para a investigação sobre Portugal e a Península Ibérica e fundamentais para o ensino da Geografia de Portugal e, sobretudo, para qualquer estudo de ordenamento do território.

Mais recentemente foram e são os temas da cartografia antiga de Portugal que têm marcado a obra de S. Daveau, também ela dirigida para a Geografia e para a História de Portugal. Tema de grande interesse pelo seu próprio valor, já fora tratado por aquela autora como elemento subsidiário para a reconstituição de fenómenos geográficos não actuais. Constituiram, até, temas de um seminário de Cartografia. Também este assunto foi ensinado por S. Daveau aos seus discípulos e

1 Professora Catedrática da Facudade de Letras da Universidade de Lisboa. Centro de Estudos Geográficos, FLUL, Cidade Universitária, 1699 Lisboa, Portugal.

2 Números 95 e 154 da lista de publicações. 
em muitas teses de doutoramento que orientou se encontra uma introdução histórica em que os mapas antigos são usados, com as devidas ressalvas, como principais fontes para reconstituir a evolução geomorfológica recente.

Relembro que em 1969, pela mão de S. Daveau, conheci a Portugaliae Monumenta Cartographica, de que nos tempos de estudante tinha ouvido falar, aquando da disciplina de História da Expansão Portuguesa e Ultramarina. Várias foram as discussões sobre mapas antigos do litoral de Moçambique, da Costa da Mina, de terras africanas tão do gosto de Suzanne Daveau.

Relembro, ainda, que este tema da Cartografia Antiga sempre foi esquecido pelos geógrafos, mesmo quando tinham preparação histórica para o tratar. Daí a ousadia de S. Daveau em continuar com os temas que dizia da «reforma», por não necessitarem trabalho de campo! E felizmente assim o têm sido, porque muito enriquecem o nosso património científico e o nosso saber.

\section{A CHEGADA DA TELEDETECÇÃO}

Pelos anos setenta foram divulgados novos documentos para o estudo geográfico da superfície da Terra; imagens captadas por satélites lançados em órbitas geo-estacionárias ou translativas, captando sinais de refletância dos objectos nos domínios espectrais da radiação visível, do infra-vermelho e das macro-ondas. Uma excelente ferramenta para quem, como Suzanne Daveau, estava perfeitamente familiarizada com a foto-interpretação e sempre se preocupara com a representação cartográfica.

Com o habitual entusiasmo pela novidade, discutia-se se a Teledetecção era uma nova técnica ou se seria uma ciência. Suzanne Daveau encarou-a como uma excelente técnica, especialmente nos domínios da Climatologia, da Morfologia e, mais tarde, da Cartografia. E entre 1975 e 1996 publicou 12 trabalhos sobre esta temática ${ }^{3}$, tendo criado uma tradição que fez escola, como se verifica pelo mais recente trabalho (ALCOFORADO et al., 1995), com alguns dos seus colaboradores. Criou, nas publicações de carácter pedagógico do Centro de Estudos Geográficos os chamados «Cadernos de Teledetecção», nos quais colaborou.

São de salientar a preocupação pedagógica manifesta nos trabalhos de discussão metodológica e mesmo nos trabalhos temáticos em que são apresentadas e discutidas as aplicações das imagens captadas no espectro infravermelho térmico. De comum têm o facto de serem imagens da parte ocidental da Península Ibérica, incluindo o próprio Oceano Atlântico, captadas pelos satélites Meteosat, NOAA e HCMM. Neles foram analisadas situações térmicas diurnas e nocturnas cujas classificações mostram a distribuição relativa da temperatura no mar e na terra, ou marcam os contrastes térmicos apenas em terra, bem acentuados na imagem do dia de verão (AlCOFORADO et al., 1995).

Regozijamo-nos em ter como mestre, colega e amiga, a homenageada geógrafa Suzanne Daveau que nos introduziu nestes dois temas, da Cartografia e da Teledetecção, a que ainda não prestamos a devida dedicação.

3 Números 87, 96, 97, 98, 107, 123, 129, 132, 134, 173, 174 e 229 da lista de publicações. 


\section{BIBLIOGRAFIA}

ALCOFORADO, M. J.; S. DAVEAU; A. LOPES; M. BAUMGARTNER (1995) - Regional Thermal Patterns in Portugal using satellite images (NOAA AVHRR). Finisterra, Revista Portuguesa de Geografia, XXX (59-60): 123-138. 